\title{
Tissue-specific changes of type 1 angiotensin II receptor and angiotensin-converting enzyme mRNA in angiotensinogen gene-knockout mice
}

\author{
K Tamura ${ }^{1}$, N Yokoyama ${ }^{1}$, Y Sumida ${ }^{1}$, T Fujita $^{1}$, E Chiba ${ }^{1}$, \\ N Tamura ${ }^{2}$, S Kobayashi ${ }^{1}$, M Kihara ${ }^{1}$, K Murakami $^{3}$, M Horiuchi $^{4}$ \\ and $\mathbf{S}$ Umemura ${ }^{1}$ \\ ${ }^{1}$ Department of Internal Medicine II, Yokohama City University School of Medicine, Yokohama 236, Japan \\ ${ }^{2}$ Department of Dermatology, Yokohama City University School of Medicine, Yokohama 236, Japan \\ ${ }^{3}$ Institute of Applied Biochemistry, University of Tsukuba, Ibaraki 305, Japan \\ ${ }^{4}$ Cardiovascular Division, Department of Medicine, Brigham and Women's Hospital, Harvard Medical School, Boston, Massachusetts 02115, USA \\ (Requests for offprints should be addressed to K Tamura, Department of Internal Medicine II, Yokohama City University School of Medicine, 3-9, Fukuura, \\ Kanazawa-ku, Yokohama 236, Japan)
}

\begin{abstract}
This study examined whether type 1 angiotensin II receptor $\left(\mathrm{AT}_{1}\right)$ and angiotensin-converting enzyme (ACE) mRNAs are regulated during dietary salt loading in angiotensinogen gene-knockout $($ Atg $-/-)$ mice which are genetically deficient in endogenous production of angiotensin II. Wild-type $(\mathrm{Atg}+/+)$ and $\mathrm{Atg}-/-$ mice were fed a normal-salt $(0.3 \% \mathrm{NaCl})$ or a high-salt $(4 \%$ $\mathrm{NaCl}$ ) diet for 2 weeks. The mRNA levels were measured by Northern blot analysis. In Atg $+/+$ mice, concentrations of plasma angiotensin peptides were decreased by salt loading, whereas the treatment increased the brainstem, cardiac, pulmonary, renal cortex, gastric and intestinal $\mathrm{AT}_{1}$ mRNA levels. Salt loading also enhanced renal cortex ACE mRNA levels in Atg $+/+$ mice. Although plasma angiotensin peptides and urinary aldosterone excretion were not detected in $A t g-/-$ mice, salt loading increased blood pressure in $\mathrm{Atg}-/-$ mice. In $\mathrm{Atg}-/-$ mice, pulmonary, renal cortex, gastric and intestinal $\mathrm{AT}_{1}$,
\end{abstract}

and renal cortex and intestinal ACE mRNA levels were higher than those in Atg $+/+$ mice. However, salt loading upregulated $\mathrm{AT}_{1}$ mRNA expression only in the liver of Atg $-/-$ mice, and the treatment did not affect ACE mRNA levels in Atg $-/-$ mice. Furthermore, although the levels of ACE enzymatic activity showed the same trend with the ACE mRNA levels in the lung, renal cortex and intestine of both Atg $-/-$ and Atg $+/+$ mice, the results of radioligand binding assay showed that cardiac expression of $\mathrm{AT}_{1}$ protein was regulated differently from $\mathrm{AT}_{1}$ mRNA expression both in Atg $-/-$ and Atg $+/+$ mice. Thus, expression of $\mathrm{AT}_{1}$ and $\mathrm{ACE}$ is regulated by salt loading in a tissue-specific manner that appears to be mediated, at least partly, by a mechanism other than changes in the circulating or tissue levels of angiotensin peptides.

Journal of Endocrinology (1999) 160, 401-408

\section{Introduction}

The renin-angiotensin system (RAS) exerts a major influence on blood pressure as well as sodium and extracellular fluid balance through the generation of angiotensin II (Ang II), which has a variety of actions such as vasoconstrictor activity and stimulation of the production and release of aldosterone. The RAS has been strongly implicated in the development of several cardiovascular diseases including hypertension, and accumulating evidence from biochemical and molecular studies of angiotensin suggests that distinct local RASs with different regulatory mechanisms from the classical circulating RAS may exist (Griendling et al. 1993, Dzau \& Re 1994).
Whether all components of local RASs are physiologically relevant is controversial, and the precise roles of these systems remain elusive, but it is interesting to speculate that a local RAS may augment the effects of Ang II on a particular tissue in specific physiological and pathophysiological processes. In addition, previous studies showed that a variety of stimuli, including blood pressure, sodium intake, inflammation, and sympathetic nerve activity, modulate the expression of the tissue RAS genes in physiological and pathophysiological states (Griendling et al. 1993, Dzau \& Re 1994, Tamura et al. 1995). Furthermore, several studies using antagonists of Ang II receptor subtypes suggest that Ang II exerts various effects on the expression of major component genes of the RAS 
by positive or negative feedback mechanisms (Kohara et al. 1992, Lassegue et al. 1995, Sechi et al. 1996).

Recently, we and others generated angiotensinogendeficient mice by gene targeting (Tanimoto et al. 1994, Kim et al. 1995, Niimura et al. 1995). Homozygous mutant $($ Atg $-/-)$ mice have no detectable plasma angiotensinogen or angiotensin peptides; they therefore lack a functional RAS and exhibit chronic hypotension. The aim of the present study was to examine whether dietary salt loading modulates the expression of major component genes of the RAS in Atg $-/-$ mice.

\section{Materials and Methods}

Animals

Atg $-/-$ mice were generated by gene targeting as described previously (Tanimoto et al. 1994). Six-week-old male $\operatorname{Atg}-/-\quad(n=16)$ and $A \operatorname{tg}+/+(n=16)$ mice were used in this study. The mice were housed under a 12/12-hour day/night cycle at a temperature of $25^{\circ} \mathrm{C}$. All animals had free access to tap water and normal rat chow containing $0 \cdot 3 \% \mathrm{NaCl}$. At 8 weeks of age, Atg $-/-$ and $A \operatorname{tg}+/+$ mice were divided into two groups and placed on either a high-salt $(4 \% \mathrm{NaCl})$ or a normal-salt $(0 \cdot 3 \% \mathrm{NaCl})$ diet. At 10 weeks of age, systolic blood pressure (SBP) was measured by tail-cuff plethysmography. Mice were killed by decapitation. Blood was centrifuged at $15000 \mathrm{~g}$ for $10 \mathrm{~min}$ at $4{ }^{\circ} \mathrm{C}$ and plasma was stored at $-80{ }^{\circ} \mathrm{C}$. Forebrain, heart, lung, liver, renal cortex, stomach and intestine were dissected out and immediately frozen in liquid nitrogen.

\section{Radioimmunoassay for plasma renin activity, angiotensin} peptides and aldosterone

Plasma renin activity (PRA) and plasma angiotensin I (Ang I) concentration were measured by a radioimmunoassay kit (RENIN RIABEAD Ang I kit, Dainabot Co., Ltd, Tokyo, Japan) (Tokita et al. 1994). Plasma Ang II concentration was determined by a specific direct radioimmunoassay, using an anti-Ang II antibody as described previously without an extraction procedure (Shimamoto et al. 1984). Before and after the experimental period, individual mice were placed in metabolic cages for 24-h urine collection. Urinary excretion of aldosterone was determined with a radioimmunoassay kit (SPAC-S aldosterone kit, Daiichi Radio-isotope Co., Tokyo, Japan).

\section{Determination of angiotensin-converting enzyme activity}

For measurement of angiotensin-converting enzyme (ACE) activity in the tissues, the tissues were homogenized in ACE homogenization buffer $(50 \mathrm{mM}$ HEPES,
pH 7·4, $150 \mathrm{mM} \mathrm{NaCl,}$ 0.5\% Triton X-100, $25 \mu \mathrm{M}$ $\mathrm{ZnCl}_{2}, 1 \mathrm{mM}$ phenylmethyl sulfonyl fluoride (PMSF)) and clarified by centrifugation for $15 \mathrm{~min}$ at $10000 \mathrm{~g}$ (Esther et al. 1996). Tissue ACE activity was measured by a spectrophotometric assay kit using 3-(2-furylacryloyl)-Lphenylalanyl-glycyl-glycine (FAPGG) as substrate (Sigma Co., St Louis, MO, USA) (Johansen et al. 1987). Total protein concentration in the tissue homogenates was calculated by the method of Lowry et al. (1951).

\section{Determination of $m R N A$ expression}

Northern blotting analysis was performed essentially as described previously (Tamura et al. 1996, 1997, 1998). Total RNA from tissues was extracted using the guanidinium thiocyanate-cesium chloride centrifugation method (Chirgwin et al. 1979). Each RNA sample $(20 \mu \mathrm{g})$ was denatured with $1 \mathrm{M}$ glyoxal and 50\% dimethyl sulfoxide, electrophoresed on $1.2 \%$ agarose gels, and transferred onto nylon membranes (GeneScreen Plus, DuPont-New England Nuclear, Boston, USA). Filters were prehybridized for $30 \mathrm{~min}$ at $60^{\circ} \mathrm{C}$ in a solution consisting of $1 \%$ sodium dodecyl sulfate (SDS), $1 \mathrm{M} \mathrm{NaCl}$, and $10 \%$ dextran sulfate. Hybridization proceeded for $18 \mathrm{~h}$ at $60{ }^{\circ} \mathrm{C}$ in the same solution containing $300 \mu \mathrm{g} / \mathrm{ml}$ denatured salmon sperm DNA and $1 \times 106$ c.p.m. $/ \mathrm{ml}$ of the ${ }^{32} \mathrm{P}-$ labeled probes for angiotensinogen (Tanimoto et al. 1994), ACE (Soubrier et al. 1988) or type 1 Ang II receptor $\left(\mathrm{AT}_{1}\right)$ (Sugaya et al. 1995). Filters were washed twice with $2 \times \mathrm{SSC}(1 \times \mathrm{SSC}=0 \cdot 15 \mathrm{M} \mathrm{NaCl}, 0 \cdot 015 \mathrm{M}$ sodium citrate) for $5 \mathrm{~min}$ at room temperature, twice with $2 \times \mathrm{SSC}$ and $1 \% \operatorname{SDS}$ for $30 \mathrm{~min}$ at $60{ }^{\circ} \mathrm{C}$, and twice with $0 \cdot 1 \times \mathrm{SSC}$ for $15 \mathrm{~min}$ at room temperature. Filters were exposed to the imaging plate of a FUJIX BIO-Imaging Analyzer BAS2000 (Fuji Photo Film). Expression of mRNA was quantified with the BAS2000 computer analyzer, and normalized to the signal generated by probing for the constitutively expressed $18 \mathrm{~S}$ ribosomal RNA gene (Raynal et al. 1984).

\section{Determination of $A T_{1}$ binding activity}

Radioligand binding assay was performed as described previously (Sumida et al. 1998). Briefly, the whole hearts were minced, homogenized, and centrifuged. The final pellet was resuspended in a buffer of $10 \mathrm{mM}$ Tris- $\mathrm{HCl}$ (pH 7.5), $3 \mathrm{mM} \mathrm{MgCl}_{2}, 1 \mathrm{mM}$ EGTA, $1 \mathrm{mM}$ PMSF, $8 \mathrm{mg} / \mathrm{ml}$ antipain, and $16 \mathrm{mg} / \mathrm{ml}$ leupeptin, and immediately used for radioligand receptor binding experiments. The incubation mixtures contained a suspension of membranes (approximately 140 to $300 \mu \mathrm{g}$ protein), $70 \mathrm{pM}$ ${ }^{125} \mathrm{I}$-[Sar $\left.{ }^{1}, \mathrm{Ile}^{8}\right]$-Ang II, incubation buffer and Ang II antagonist (Sar ${ }^{1}$,Ile ${ }^{8}$ Ang II, CV-11974) at various concentrations $(10 \mathrm{pM}-10 \mathrm{mM})$, in a final volume of $200 \mu \mathrm{l}$. The samples were incubated for $120 \mathrm{~min}$ at $22^{\circ} \mathrm{C}$, followed by three washes with ice-cold buffer containing 
$10 \mathrm{mM}$ Tris-HCl, $1 \mathrm{mM}$ EGTA, $3 \mathrm{mM} \mathrm{MgCl}_{2}$, and $2 \mathrm{mg} / \mathrm{ml}$ bovine serum albumin. The radioactivity trapped on the filters was quantified with an automatic gamma counter (Beckman Gamma 5500). Nonspecific binding of ${ }^{125} \mathrm{I}$-[Sar $\left.{ }^{1}, \mathrm{Ile}^{8}\right]$-Ang II was defined as the radioactivity that bound to membrane fractions and was not displaced by a high concentration of unlabeled $\mathrm{Sar}^{1}$,Ile ${ }^{8}$-Ang II (1 mM).

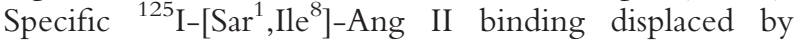
CV-11974 was estimated as $\mathrm{AT}_{1}$. Each binding assay was carried out in duplicate. Maximum binding capacity $\left(\mathrm{B}_{\max }\right)$ and dissociation constant $\left(K_{\mathrm{d}}\right)$ were analyzed with the LIGAND computer program.

\section{Statistics}

For statistical analysis of differences among groups, the unpaired Student's $t$-test or analysis of variance followed by Scheffe's F-test were used. All quantitative data are expressed as means \pm S.E. A value of $P<0.05$ was considered to be statistically significant.

\section{Results}

$S B P, P R A$, plasma angiotensin peptides and urinary aldosterone in Atg $+/+$ and Atg $-/-$ mice

As shown in Fig. 1, body weight of Atg $-/-$ mice at 10 weeks was lower than that of $A t g+/+$ mice. When fed the normal-salt diet, Atg $-/-$ mice had significantly lower SBP. In Atg $-/-$ mice, SBP was significantly increased by the high-salt diet, whereas this diet had no effect on SBP in Atg $+/+$ mice. PRA, plasma Ang I and Ang II concentrations and urinary aldosterone excretion were below the detection limit of the assay systems in Atg $-/-$ mice, and were significantly decreased in $\mathrm{Atg}+/+$ mice when fed the high-salt diet.

Tissue RAS gene expression in Atg $+/+$ and Atg $-/-$ mice

Since angiotensinogen, which is the unique substrate of RAS and has been strongly suggested to be involved in human hypertension, is abundantly expressed in the liver and brainstem, we first examined the expression of angiotensinogen mRNA in these tissues of $\mathrm{Atg}+/+$ and Atg $-/-$ mice and analyzed the effect of salt-loading on expression by Northern blot analysis (Fig. 2). The BAS2000 analyzer system used in this study is able to count radioactivity directly from the imaging plate which is exposed to radioactive material (Amemiya \& Miyahara 1988). The imaging plate of BAS2000 is more sensitive (about 100-fold) than the conventional X-ray film in the detection of radioactivity, and has a wide dynamic range with good linear relationship with radioactivity, thus allowing us to calculate accurately the mRNA value. We
A
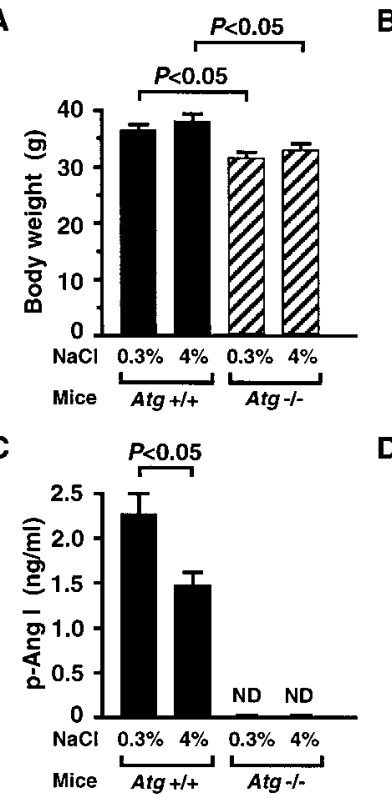

E

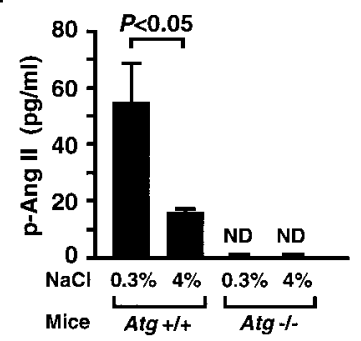

B

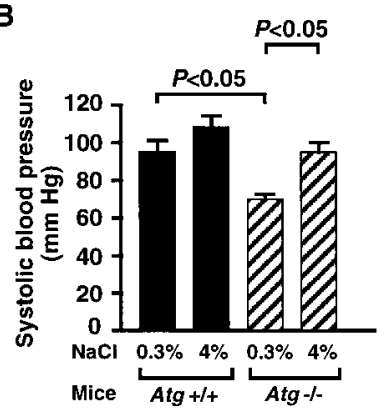

D

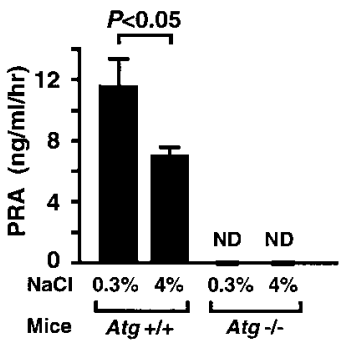

$\mathbf{F}$

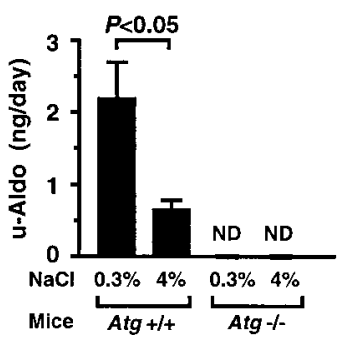

Figure 1 (A) Body weight, (B) systolic blood pressure, (C) plasma (p) Ang I concentration, (D) PRA, (E) plasma (p) Ang II concentration and (F) urinary (u) aldosterone excretion in Atg $+/+$ and Atg $-/-$ mice fed a normal-salt $(0 \cdot 3 \% \mathrm{NaCl})$ or a high-salt $(4 \% \mathrm{NaCl})$ diet for 2 weeks. Values are means \pm S.E. $(n=8)$. ND, not detected.

repeated the quantitation of the mRNA value and used the data from two independent experiments. Angiotensinogen mRNA is expressed in Atg $+/+$ mice but not in $A t g-/-$ mice and the high-salt diet had no significant effect on the levels of hepatic and brainstem angiotensinogen mRNA. Both hepatic and brainstem $\mathrm{AT}_{1}$ mRNA levels in $A t g+/+$ mice were comparable to those in Atg $-/-$ mice fed the normal-salt diet. In Atg $+/+$ mice, the high-salt diet significantly increased the brainstem $\mathrm{AT}_{1}$ mRNA levels, whereas in Atg $-/-$ mice the high-salt diet increased the hepatic $\mathrm{AT}_{1}$ mRNA levels.

As shown in Fig. 3, Atg $-/-$ mice had higher levels of pulmonary and renal cortex $\mathrm{AT}_{1}$ mRNA expression than Atg $+/+$ mice when fed the normal-salt diet. The high-salt diet significantly increased the pulmonary and renal cortex $\mathrm{AT}_{1}$ mRNA levels in Atg $+/+$ mice. In $A t g-/-$ mice, the treatment decreased the pulmonary $\mathrm{AT}_{1}$ mRNA levels but did not affect the renal cortex $\mathrm{AT}_{1}$ mRNA levels. 
A

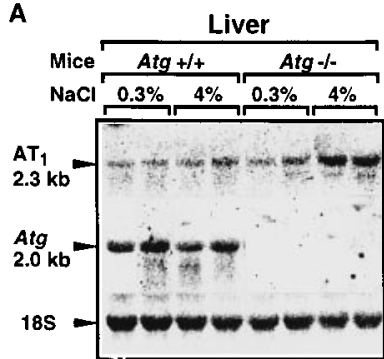

$\mathbf{B}$
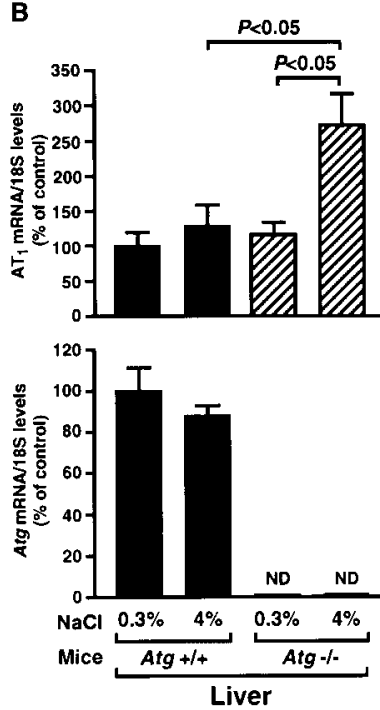

Brainstem
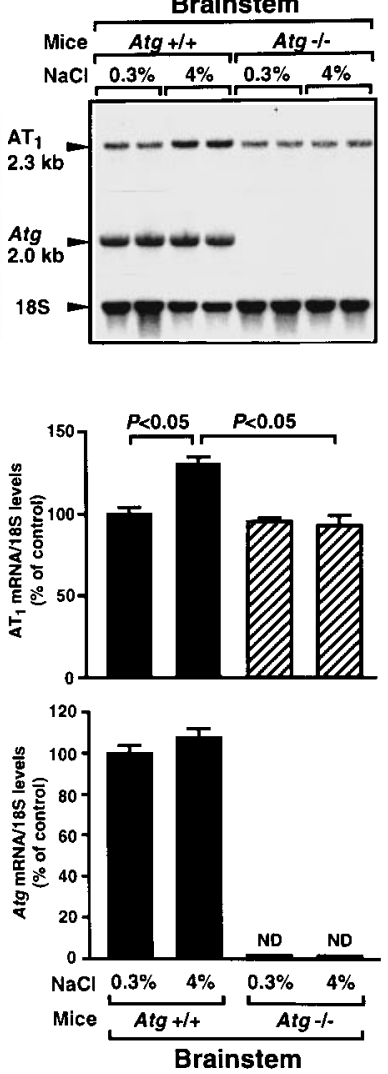

Figure 2 Expression of $A T_{1}$ and angiotensinogen (Atg) mRNA in the liver and brainstem of Atg $+/+$ and $A t g-/-$ mice fed a normal-salt $(0 \cdot 3 \% \mathrm{NaCl})$ or a high-salt $(4 \% \mathrm{NaCl})$ diet for 2 weeks. (A) Representative results of Northern blot analysis of total RNA $(20 \mu \mathrm{g})$ for $\mathrm{AT}_{1}$ and Atg mRNA and $18 \mathrm{~S}$ ribosomal RNA (18S). (B) Bar graphs show relative $\mathrm{AT}_{1}$ and Atg mRNA levels. The mRNA levels were measured using a BAS2000 Imaging Analyzer, normalized to the signal generated by probing for $18 \mathrm{~S}$, and expressed relative to those achieved with RNA from tissues of Atg $+/+$ mice fed a normal-salt $(0 \cdot 3 \% \mathrm{NaCl})$ diet. Values are means \pm S.E. $(n=8)$. ND, not detected.

With respect to the regulation of ACE gene, the levels of pulmonary ACE mRNA expression were similar between Atg $+/+$ and Atg $-/-$ mice when fed the normal-salt diet, and the high-salt diet had no significant effect on such levels. In the renal cortex, Atg $-/-$ mice had higher levels of ACE mRNA expression than Atg $+/+$ mice when fed the normal-salt diet, and the high-salt diet significantly increased ACE mRNA levels in Atg $+/+$ mice. The renal cortex ACE mRNA levels in Atg $+/+$ mice were comparable to those in $A t g-/-$ mice fed the high-salt diet.

We also examined the expression of RAS component mRNAs in the gastrointestinal tract (Fig. 4). Atg $-/-$ mice had higher levels of gastric and intestinal $\mathrm{AT}_{1}$ mRNA expression than Atg $+/+$ mice when fed the

A
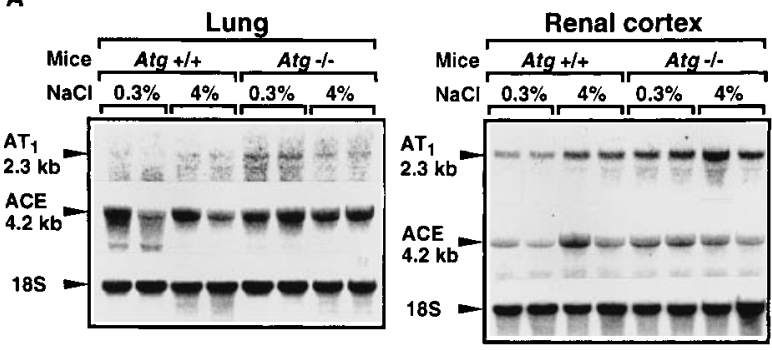

B
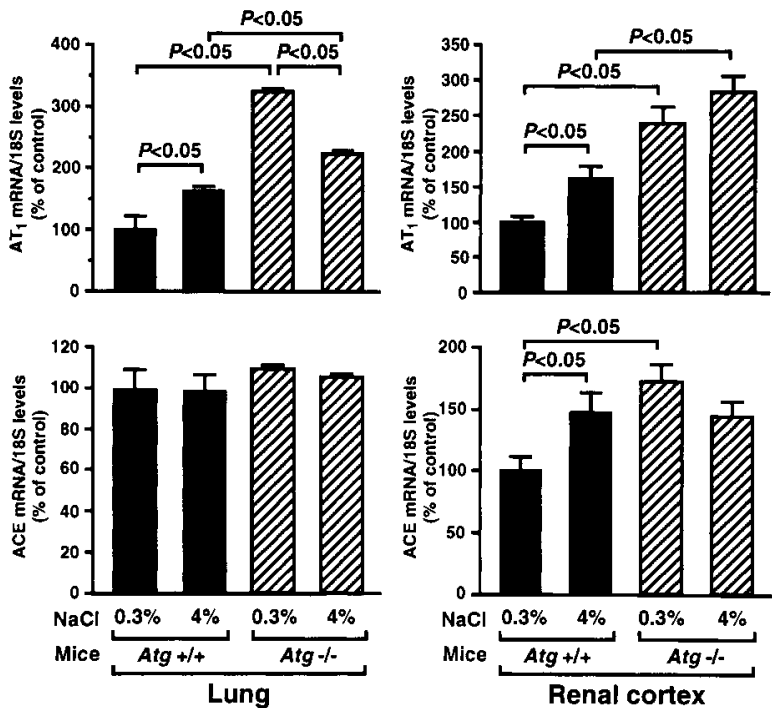

Figure 3 Expression of $\mathrm{AT}_{1}$ and $\mathrm{ACE} m \mathrm{mNA}$ in the lung and renal cortex of $\mathrm{Atg}+\mathrm{I}+$ and $\mathrm{Atg}-\mathrm{/}-$ mice fed a normal-salt $(0 \cdot 3 \%$

$\mathrm{NaCl})$ or a high-salt $(4 \% \mathrm{NaCl})$ diet for 2 weeks. (A) Representative results of Northern blot analysis of total RNA (20 $\mu \mathrm{g})$ for $\mathrm{AT}_{1}$ and ACE mRNA and $18 \mathrm{~S}$ ribosomal RNA (18S). (B) Bar graphs show relative $A_{1}$ and $A C E m R N A$ levels. The mRNA levels were measured as described in the legend of Fig. 1. Values are means \pm S.E. $(n=8)$.

normal-salt diet, and the high-salt diet significantly increased the gastric and intestinal $\mathrm{AT}_{1} \mathrm{mRNA}$ levels in Atg $+/+$ mice but not in Atg $-/-$ mice. The gastric angiotensinogen mRNA is expressed in $A t g+/+$ mice but not in $A t g-/-$ mice and the high-salt diet increased gastric angiotensinogen mRNA levels in $A t g+/+$ mice. Atg $-/-$ mice had higher levels of ACE mRNA expression than $A t g+/+$ mice both on normal- and high-salt diets. The levels of ACE enzymatic activity showed the same trend with the ACE mRNA levels in the lung, renal cortex and intestine of both $\operatorname{Atg}-/-$ and $\operatorname{Atg}+/+$ mice (Table 1).

Finally, to examine whether angiotensin binding to receptor is altered in relation to differences in $\mathrm{AT}_{1}$ mRNA levels in Atg $-/-$ mice, we performed Northern blot analysis and radioligand binding assay of $\mathrm{AT}_{1}$ using hearts from $A t g-/-$ and $A t g+/+$ mice (Fig. 5). The levels of 
A
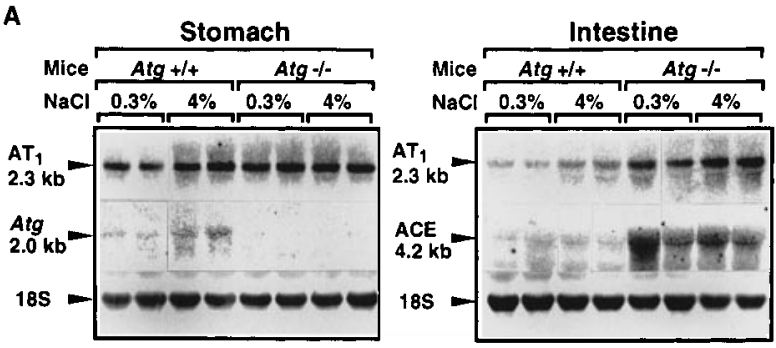

$\mathbf{B}$
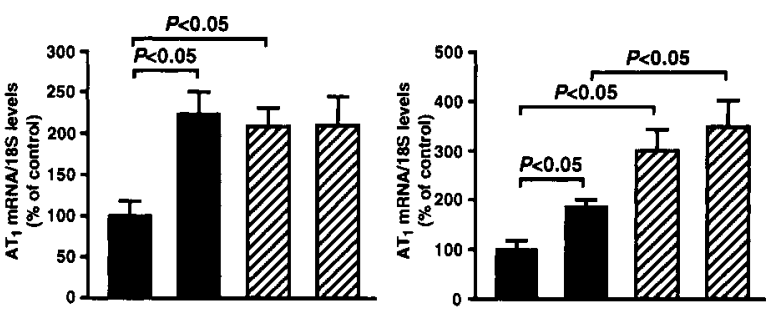

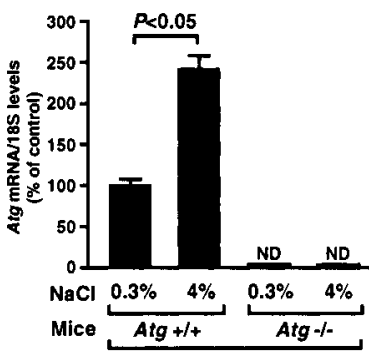

Stomach

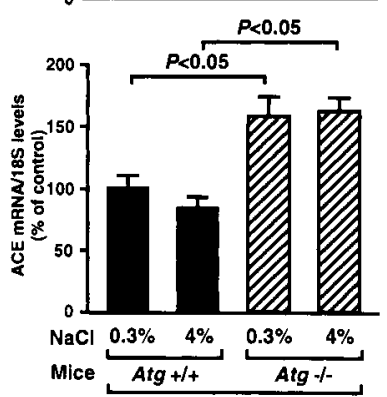

Intestine
Figure 4 Expression of $\mathrm{AT}_{1}$ and angiotensinogen $(\mathrm{Atg})$ in the stomach, and of $\mathrm{AT}_{1}$ and ACE mRNA in the intestine of Atg +/+ and Atg $-/-$ mice fed a normal-salt $(0 \cdot 3 \% \mathrm{NaCl})$ or a high-salt $(4 \% \mathrm{NaCl})$ diet for 2 weeks. (A) Representative results of Northern blot analysis of total RNA $(20 \mu \mathrm{g})$ for $\mathrm{AT}_{1}$, Atg and ACE mRNA and $18 \mathrm{~S}$ ribosomal RNA (18S). (B) Bar graphs show relative $\mathrm{AT}_{1}$, Atg and ACE mRNA levels. The mRNA levels were measured as described in the legend of Fig. 1 . Values are means \pm S.E. $(n=8)$. ND, not detected.

cardiac $\mathrm{AT}_{1}$ mRNA expression were similar in Atg $+/+$ and $A t g-/-$ mice fed the normal-salt diet. The high-salt diet significantly increased $\mathrm{AT}_{1}$ mRNA levels in $\mathrm{Atg}+/+$ mice, whereas the treatment did not affect cardiac $\mathrm{AT}_{1}$ mRNA levels in Atg $-/-$ mice. On the other hand, the results of radioligand binding assay showed that $\mathrm{B}_{\max }$ of $\mathrm{AT}_{1}$ was significantly increased in $\mathrm{Atg}-/-$ mice compared with $A t g+/+$ mice both on normal- and high-salt diets, although $K_{\mathrm{d}}$ was not different among the four groups.

\section{Discussion}

Previous studies of regulation of the RAS components in genetically or experimentally hypertensive animals showed widespread abnormalities of RAS gene expression which were modulated in some tissues by the development of hypertension. However, little is known about regulation of the RAS genes in hypotensive animals. Since Atg $-/-$ mice do not produce angiotensin peptides at all and thus are chronically hypotensive, Atg $-/-$ mice may be a genetically suitable hypotension model for analysis of the regulation of RAS gene expression in vivo. The present study was performed to examine the effect of a high sodium intake on the expression of RAS (in particular $\mathrm{AT}_{1}$ ) genes in the tissues of Atg $-/-$ mice which completely lack endogenous production of Ang II, and we showed that salt loading significantly increased SBP in $\operatorname{Atg}-/-$ mice and that expression of the RAS genes was regulated in a tissue-specific manner by salt loading in Atg $-1-$ mice.

It is well known that conditions of increased RAS activity cause downregulation of $\mathrm{AT}_{1}$, whereas a decrease in the activity of the RAS upregulates the $\mathrm{AT}_{1}$. Previous studies showed that dietary salt loading enhanced the expression of $\mathrm{AT}_{1} \mathrm{mRNA}$ in the brainstem and kidney (Sandberg et al. 1994, Jo et al. 1996, Sechi et al. 1996), and one of the possible mechanisms involved in salt-mediated regulation of $\mathrm{AT}_{1}$ is changes of circulating Ang II levels; changes in sodium intake exert effects on the expression of $\mathrm{AT}_{1}$ genes, and the elevation or suppression of circulating Ang II accompanying restriction of sodium intake or sodium loading respectively may be involved in these effects (Aguilera \& Catt 1981, Catt et al. 1984, Wang \& Du 1998). Dietary sodium loading is known to suppress

Table 1 Tissue ACE activities of Atg $+/+$ and Atg $-/-$ mice fed a normal- or high-salt diet. ACE activities are expressed as units/mg tissue protein. Values are means \pm S.E; $n=8$ mice in each group

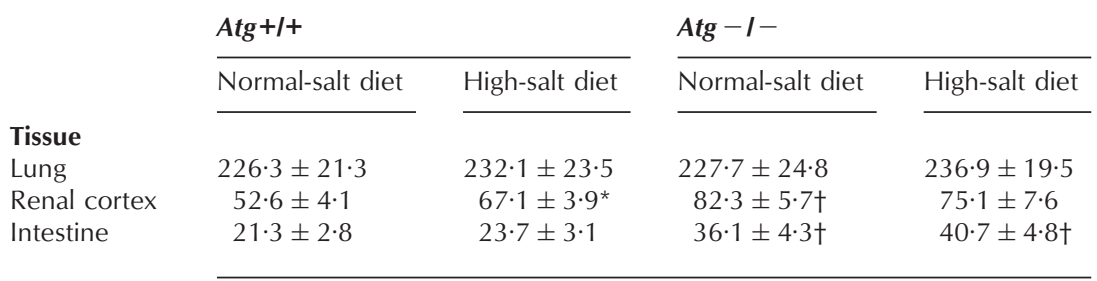

${ }^{*} P<0.05$ vs normal-salt diet, $+P<0.05$ vs $A t g+/+$ mice within the same salt diet group. 

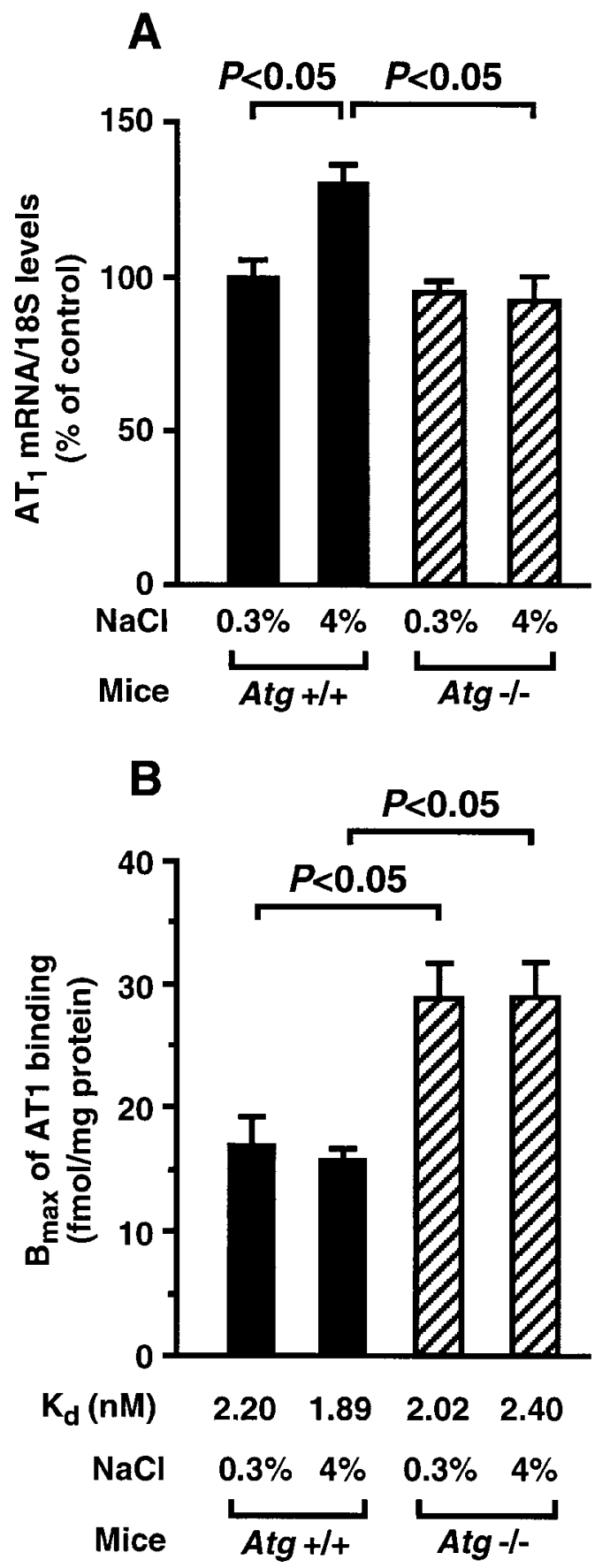

Figure 5 Expression of $\mathrm{AT}_{1} \mathrm{mRNA}$ and receptor protein in the heart of $A t g+/+$ and $A t g-/-$ mice fed a normal-salt $(0 \cdot 3 \% \mathrm{NaCl})$ or a high-salt $(4 \% \mathrm{NaCl})$ diet for 2 weeks. (A) Bar graphs show relative $\mathrm{AT}_{1}$ mRNA levels of Northern blot analysis of total RNA $(20 \mu \mathrm{g})$. The mRNA levels were measured as described in the legend of Fig. 1. Values are means \pm S.E. $(n=4)$. (B) Bar graphs show cardiac radioligand binding activity of $\mathrm{AT}_{1}$. Membrane solution prepared from mouse heart was incubated with ${ }^{125} \mathrm{I}-\left[\mathrm{Sar}^{1}, \mathrm{Ile}^{8}\right]$-Ang II, and $\mathrm{AT}_{1}$ binding activity was determined by competition binding experiments using Ang II antagonists ( ${ }^{125} \mathrm{I}-\left[\mathrm{Sar}^{1}, \mathrm{Ile}^{8}\right]$-Ang II and CV-11974). the circulating RAS and to decrease circulating levels of Ang II. In this study, salt loading increased $\mathrm{AT}_{1}$ mRNA levels in the brainstem, lung, renal cortex, stomach, intestine and heart of $\mathrm{Atg}+/+$ mice, and $\mathrm{Atg}-/ \mathrm{-}$ mice had higher levels of pulmonary, renal cortex, gastric and intestinal $\mathrm{AT}_{1}$ mRNA than Atg $+/+$ mice when fed the normal-salt diet. Because Ang II downregulates expression of the $\mathrm{AT}_{1}$ gene (Lassegue et al. 1995, Nickenig \& Murphy 1996), the decrease in circulating and tissue Ang II levels by salt loading in $A t g+/+$ mice and the genetic deficiency of endogenous production of Ang II in Atg $-/-$ mice may be involved in the upregulation of $\mathrm{AT}_{1}$ gene expression in the lung, renal cortex, stomach and intestine.

On the other hand, there was no difference in $\mathrm{AT}_{1}$ mRNA expression in the liver, brainstem and heart between Atg $+/+$ and Atg $-/-$ mice when fed the normal-salt diet. In these tissues, salt loading increased the brainstem and cardiac $\mathrm{AT}_{1}$ mRNA levels in $A t g+/+$ mice but not in $A t g-/-$ mice, and the treatment enhanced the hepatic $\mathrm{AT}_{1}$ mRNA levels in Atg $-/-$ mice but not in $A t g+/+$ mice. Thus, complete lack of angiotensin peptides may affect the salt-mediated regulation of $\mathrm{AT}_{1}$ gene in these tissues while the basal expression of $\mathrm{AT}_{1}$ gene is similar in Atg $+/+$ and $A t g-/-$ mice. Ang II is well known to be a potent inhibitor of renin production in the kidney. However, in our recent study using Atg $-/-$ mice, the neuronal-type nitric oxide synthase (N-NOS) expression in the macula densa is inversely regulated by salt intake and the enzyme activity is functionally linked to renal renin production, thereby suggesting that saltmodulated renal N-NOS and renin expressions are independent of angiotensin formation in $\operatorname{Atg}-/-$ mice (Kihara et al. 1998). Based on our results, there are obviously additional factors other than Ang II that may influence the salt-mediated expression of $\mathrm{AT}_{1}$, as with the renal renin expression. Although the mechanisms responsible for these different responses to salt loading between Atg $+/+$ and $A t g-/-$ mice are not known, several recent studies indicated sodium chloride itself was capable of upregulating the vascular $\mathrm{AT}_{1}$ gene expression independently of Ang II in vitro and in vivo (Nickenig et al. 1998, Wang \& Du 1998). In addition, it is known that changes in osmolarity in the sense of hypotonic or hypertonic stress induce second messenger pathways such as calcium, cAMP, inositol phosphate and the mitogen-activated protein (MAP) kinase cascade (Maeda et al. 1994, Sadoshima et al. 1996), although the intracellular pathways mediating salt-induced modulation of $\mathrm{AT}_{1}$ expression are unknown. Previous studies showed that aldosterone and glucocorticoid increased expression of the $\mathrm{AT}_{1}$ gene whereas the expression was downregulated by phorbol esters, estrogens, and Ang II (Ullian et al. 1992, Sato et al. 1994). In the present study, the urinary excretion of aldosterone is not detectable in Atg $-/-$ mice, although others have found an angiotensin-independent mechanism 
for aldosterone synthesis, in particular, during chronic depletion of extracellular fluid volume in $\mathrm{Atg}-/-$ mice (Okubo et al. 1997). Furthermore, the vasopressin and catecholaminergic systems may be altered by lack of angiotensin peptides in $\mathrm{Atg}-/-$ mice (Umemura et al. 1998). Therefore, it is possible that alterations of hormonal levels and signaling pathways in Atg $-/-$ mice may change the ultimate response of regulation of $\mathrm{AT}_{1}$ gene by Ang II in a tissue-specific manner.

In the present study we found a discrepancy between $\mathrm{AT}_{1}$ mRNA and protein levels in the heart of $\mathrm{Atg}+/+$ and Atg $-/-$ mice, although $\mathrm{AT}_{1}$ protein contents were not analyzed in other tissues. Examples of dissociation between mRNA levels and protein contents are known to occur, and a previous study showed that Ang II infusion had no effect on $\mathrm{AT}_{1}$ mRNA levels but that it downregulated $\mathrm{AT}_{1}$ density through a posttranscriptional mechanism (Sechi et al. 1996). Further studies are clearly needed to elucidate a mechanism responsible for posttranscriptional modulation induced by genetic deficiency of angiotensin peptides.

Although tissue ACE may play an important role in the local production of Ang II (Johnston 1994), little is known regarding the regulation of the tissue ACE gene by altered sodium intake. Previous studies showed a significant increase in ACE mRNA in response to a high-sodium diet and an Ang II-mediated downregulation of ACE gene expression in rats (Schunkert et al. 1993, Kreutz et al. 1995). In the present study, Atg - / - mice had higher levels of renal cortex and intestinal ACE mRNA than Atg $+/+$ mice when fed the normal-salt diet. However, salt loading increased the renal cortex ACE mRNA levels in Atg $+/+$ mice, but the treatment had no effect on renal cortex ACE mRNA in Atg $-/-$ mice. Thus, complete lack of angiotensin peptides may make the ACE gene unable to respond to salt loading in the tissues of $\mathrm{Atg}-/-$ mice. Similar to the case of $\mathrm{AT}_{1}$, ACE gene expression is regulated by glucocorticoid (Dasarathy et al. 1992, Fishel et al. 1995), and it is also possible that alterations of hormonal levels and signaling pathways in Atg $-/-$ mice may change the ultimate response of regulation of ACE gene by Ang II in a tissue-specific manner. Furthermore, ACE plays an important role in both the RAS and the kinin-kallekrein system. Therefore, enhanced ACE activities in the kidney and intestine of Atg - / - mice may have several influences on the physiological functions of these tissues through the possible effect of ACE on the kinin-kallekrein system, although further studies are obviously needed to clarify this issue.

In conclusion, the findings obtained in the present study suggest that dietary salt loading exerts its systemic influence on the RAS component genes differently in $\mathrm{Atg}+/+$ and Atg $-/-$ mice. Future research must elucidate the systemic and cellular mechanisms by which salt intake modulates the expression of RAS genes and the possible roles of angiotensin peptides in these mechanisms.

\section{Acknowledgements}

This work was supported in part by grants from the Ministry of Education, Science, and Culture of Japan, the Uehara Memorial Foundation, Ichiro Kanehara Foundation, and Yokohama Foundation for Advancement of Medical Science. Dr Kouichi Tamura is supported by a Postdoctoral Fellowship for Research Abroad of the Japan Society for the Promotion of Science.

\section{References}

Aguilera G \& Catt K 1981 Regulation of vascular angiotensin II receptors in the rat during altered sodium intake. Circulation Research $49751-758$.

Amemiya Y \& Miyahara J 1988 Imaging plate illuminates many fields. Nature 336 89-90.

Catt KJ, Mendelsohn FAC, Millan MA \& Aguilera G 1984 The role of angiotensin II receptors in vascular regulation. Journal of Cardiovascular Pharmacology 6 S575-S586.

Chirgwin JM, Pryzbyla AE, MacDonald RJ \& Rutter WJ 1979 Isolation of biologically active ribonucleic acid from sources enriched in nuclease. Biochemistry 18 5294-5299.

Dasarathy Y, Lanzillo JJ \& Fanburg BI 1992 Stimulation of bovine pulmonary artery endothelial cell ACE by dexamethasone: involvement of steroid receptors. American Journal of Physiology 263 L645-L649.

Dzau VJ \& Re R 1994 Tissue angiotensin system in cardiovascular medicine: a paradigm shift? Circulation 89 493-498.

Esther CR Jr, Howard TE, Marino EM, Goddard JM, Capecchi MR \& Bernstein KE 1996 Mice lacking angiotensin-converting enzyme have low blood pressure, renal pathology, and reduced male fertility. Laboratory Investigation 74 953-965.

Fishel RS, Eisenberg S, Shai SY, Redden RA, Bernstein KE \& Berk BC 1995 Glucocorticoids induce angiotensin-converting enzyme expression in vascular smooth muscle. Hypertension 25 343-349.

Griendling KK, Murphy TJ \& Alexander RW 1993 Molecular biology of the renin-angiotensin system. Circulation 87 1816-1828.

Jo H, Yang E-K, Lee W-J, Park K-Y, Kim H-J \& Park J-S 1996 Gene expression of central and peripheral renin-angiotensin system components upon dietary sodium intake in rats. Regulatory Peptides 67 115-121.

Johansen KB, Marstein S \& Aas P 1987 Automated method for the determination of angiotensin-converting enzyme in serum. Scandinavian Journal of Clinical and Laboratory Investigation 47 411-414.

Johnston CI 1994 Tissue angiotensin converting enzyme in cardiac and vascular hypertrophy, repair, and remodeling. Hypertension $\mathbf{2 3}$ 258-268.

Kihara M, Umemura S, Yabana M, Sumida Y, Nyui N, Tamura K, Kadota T, Kishida R, Murakami K, Fukamizu A \& Ishii M 1998 Dietary salt loading decreases the expression of neuronal-type nitric oxide synthase and renin in the juxtaglomerular apparatus of angiotensinogen gene-knockout mice. Journal of American Society of Nephrology 9 355-362.

Kim H-S, Krege JH, Kluckman KD, Hagaman JR, Hodgin JB, Best CF, Jennette JC, Coffman TM, Maeda N \& Smithies O 1995 Genetic control of blood pressure and the angiotensinogen locus. Proceedings of the National Academy of Sciences of the USA 92 2735-2739.

Kohara K, Brosnihan KB, Ferrario CM \& Milsted A 1992 Peripheral and central angiotensin II regulates expression of genes of the renin-angiotensin system. American Journal of Physiology 262 E651-E657. 
Kreutz R, Fernandez Alfonso MS, Liu Y, Ganten D \& Paul M 1995 Induction of cardiac angiotensin I-converting enzyme with dietary $\mathrm{NaCl}$-loading in genetically hypertensive and normotensive rats. Journal of Molecular Medicine 73 243-248.

Lassegue B, Alexander RW, Nickenig G, Clark M, Murphy TJ \& Griendling KK 1995 Angiotensin II down-regulates the vascular smooth muscle $\mathrm{AT}_{1}$ receptor by transcriptional and posttranscriptional mechanisms: evidence for homologous and heterologous regulation. Molecular Pharmacology 48 601-609.

Lowry OH, Rosebrough NJ, Farr AL \& Randall RJ 1951 Protein measurement with the folin phenol reagent. Journal of Biological Chemistry 193 265-275.

Maeda T, Wurgler-Murphy SH \& Saito H 1994 A two-component system that regulates an osmosensing MAP kinase cascade in yeast. Nature 369 242-245.

Nickenig G \& Murphy TJ 1996 Enhanced AT $_{1}$ receptor mRNA degradation and induction of polyribosomal mRNA binding proteins by angiotensin II in vascular smooth muscle cells. Molecular Pharmacology 50 743-751.

Nickenig G, Strehlow K, Roeling J, Zolk O, Knorr A \& Böhm M 1998 Salt induces vascular $\mathrm{AT}_{1}$ receptor overexpression in vitro and in vivo. Hypertension 31 1272-1277.

Niimura F, Labosky PA, Kakuchi J, Okubo S, Yoshida H, Oikawa T, Ichiki T, Naftilan AJ, Fogo A, Inagami T, Hogan BLM \& Ichikawa I 1995 Gene targeting in mice reveals a requirement for angiotensin in the development and maintenance of kidney morphology and growth factor regulation. Journal of Clinical Investigation 96 2947-2954.

Okubo S, Niimura F, Nishimura H, Takemoto F, Fogo A, Matsusaka T \& Ichikawa I 1997 Angiotensin-independent mechanism for aldosterone synthesis during chronic extracellular fluid volume depletion. Journal of Clinical Investigation 99 855-860.

Raynal F, Michot B \& Bachellerie J-P 1984 Complete nucleotide sequence of mouse $18 \mathrm{~S}$ rRNA gene: comparison with other available homologs. FEBS Letters 167 263-268.

Sadoshima J, Qiu Z, Morgan JP \& Izumo S 1996 Tyrosine kinase activation is an immediate and essential step in hypotonic cell swelling-induced ERK activation and c-fos gene expression in cardiac myocytes. EMBO Journal 15 5535-5546.

Sandberg K, Ji H \& Catt KJ 1994 Regulation of angiotensin II receptors in rat brain during dietary sodium changes. Hypertension 23 I137-I141.

Sato A, Suzuki H, Murakami M, Nakazato Y, Iwaita Y \& Saruta T 1994 Glucocorticoid increases angiotensin II type 1 receptor and its gene expression. Hypertension 23 25-30.

Schunkert H, Ingelfinger JR, Hirsch AT, Pinto Y, Remme WJ, Jacob H \& Dzau VJ 1993 Feedback regulation of angiotensin converting enzyme activity and mRNA levels by angiotensin II. Circulation Research 72 312-318.

Sechi LA, Griffin CA, Giacchetti G, Valentin JP, Llorens-Cortes C, Corvol P \& Schambelan M 1996 Tissue-specific regulation of type 1 angiotensin II receptor mRNA levels in the rat. Hypertension $\mathbf{2 8}$ 403-408

Shimamoto K, Ishida H, Nakahashi Y, Nishitani T, Hosoda S, Yokoyama T, Tanaka S \& Iimura O 1984 A very sensitive direct radioimmunoassay system for plasma angiotensin II and its clinical application in various hypertensive diseases. Japanese Circulation Journal 48 1228-1235.
Soubrier F, Alhenc-Gelas F, Hubert C, Allegrini J, John M, Tregear G \& Corvol P 1988 Two putative active centers in human angiotensin I-converting enzyme revealed by molecular cloning. Proceedings of the National Academy of Sciences of the USA $\mathbf{8 5}$ 9386-9390.

Sugaya T, Nishimatsu S, Tanimoto K, Takimoto E, Yamagishi T, Imamura K, Goto S, Imaizumi K, Hisada Y, Otsuka A, Uchida H, Sugiura M, Fukuta K, Fukamizu A \& Murakami K 1995 Angiotensin type 1a receptor-deficient mice with hypotension and hyperreninemia. Journal of Biological Chemistry 270 18719-18722.

Sumida Y, Umemura S, Tamura K, Kihara M, Kobayashi S, Ishigami T, Yabana M, Nyui N, Ochiai H, Fukamizu A, Miyazaki H, Murakami K \& Ishii M 1998 Increased cardiac angiotensin II receptors in angiotensinogen-deficient mice. Hypertension $\mathbf{3 1}$ $45-49$.

Tamura K, Umemura S, Fukamizu A, Ishii M \& Murakami K 1995 Recent advances in the study of renin and angiotensinogen genes: from molecules to the whole body. Hypertension Research 18 $7-18$.

Tamura K, Umemura S, Nyui N, Yamakawa T, Yamaguchi S, Ishigami T, Tanaka S, Tanimoto K, Takagi N, Sekihara $\mathrm{H}$, Murakami K \& Ishii M 1996 Tissue specific regulation of angiotensinogen gene expression in spontaneously hypertensive rat. Hypertension 27 1216-1223.

Tamura K, Umemura S, Yamakawa T, Nyui N, Hibi K, Watanabe Y, Ishigami T, Yabana M, Tanaka S, Sekihara H, Murakami K \& Ishii M 1997 Modulation of tissue angiotensinogen gene expression in genetically obese hypertensive rats. American Journal of Physiology 272 R1704-R1711.

Tamura K, Umemura S, Sumida Y, Nyui N, Kobayashi S, Ishigami T, Kihara M, Sugaya T, Fukamizu A, Miyazaki H, Murakami K \& Ishii M 1998 Effect of genetic deficiency of angiotensinogen on renin-angiotensin system. Hypertension 32 223-227.

Tanimoto K, Sugiyama F, Goto Y, Ishida J, Takimoto E, Yagami K, Fukamizu A \& Murakami K 1994 Angiotensinogen-deficient mice with hypotension. Journal of Biological Chemistry 269 31334-31337.

Tokita Y, Franco-Saenz R, Reimann EM \& Mulrow PJ 1994 Hypertension in the transgenic rat TGR(mRen-2)27 may be due to enhanced kinetics of the reaction between mouse renin and rat angiotensinogen. Hypertension 23 422-427.

Ullian ME, Schelling JR \& Linas SL 1992 Aldosterone enhances angiotensin II receptor binding and inositol phosphate responses. Hypertension 20 67-73.

Umemura S, Kihara M, Sumida Y, Yabana M, Ishigami T, Tamura K, Nyui N, Hibi K, Murakami K, Fukamizu A \& Ishii M 1998 Endocrinological abnormalities in angiotensinogen-gene knockout mice: studies of hormonal responses to dietary salt loading. Journal of Hypertension 16 285-289.

Wang DH \& Du Y 1998 Regulation of vascular type 1 angiotensin II receptor in hypertension and sodium loading: role of angiotensin II. Journal of Hypertension 16 467-475.

Received 5 June 1998

Revised manuscript received 17 August 1998 Accepted 20 October 1998 